\title{
The Application of Good Work Motivation to Increase Employee Productivity Salam Indonesia Travel
}

\author{
Huwaidaul Azkiya, Setyo Riyanto \\ Mercu Buana University, Jakarta, Indonesia \\ Mercu Buana University, Jakarta, Indonesia \\ Email: huwaidaadzkiya@gmail.com and setyo.riyanto@mercubuana.ac.id
}

\section{ARTICLE INFO}

Date received : 20 August 2020

Revision date : 03 September 2020

Date received : 19 October 2020

Keywords:

Motivation

Work motivation

Work productivity

Employee productivity

Employee performance

\begin{abstract}
The main reason for compiling this journal is to find out the application of good work motivation to increase employee productivity salam Indonesia travel. The research method used in this study is qualitative descriptive. Information collection procedures utilized in this study are the strategy of perception, interviews, and documentation considers. Information examination procedures in this study include the steps of data reduction, data display, and drawing conclusions. The result of the study found that the Motivation must be applied because it is one of the most important components in supporting the efficiency of worker productivity, without motivation, an employee will lose enthusiasm for work. The leader of Salam Indonesia Travel in increasing employee motivation using methods that are appropriate to the situation of the company and employees. Because every employee has different behaviors and actions at work, so the provision of motivation must be different as well. Highly motivated individuals mean that these people have a compelling reason to get the job done as the company wants. Conversely, when individuals have low motivation, they cannot work well together to achieve the desired performance efficiency of the company.
\end{abstract}

\section{INTRODUCTION}

In an organization or company having human resources is the most important thing. Because human resources play a role in driving and controlling activities in an organization or company. All organizations or companies will certainly do everything they can to create a quality performance for their employees with good human resource management (Riyanto, Sutrisno, \& Ali, 2017). Therefore, companies must always encourage employees with high enthusiasm to create and maintain superior human resources and be able to compete. Motivating employees is done for the progress and goals of the company's success. High work motivation will make workers more active in doing their jobs. Meanwhile, when a worker has low motivation, the implementation of his work is also low, provide up easily, and have inconvenience doing their work.

The mystery of motivation and performance is revealed by psychologists to find the root cause of motivation and demotivation in individuals, especially in an organization. According to psychologists such as Maslow's needs theory and Herzberg's two-factor theory, that salaries or wages, systems and procedures, facilities and working 
conditions are basic needs that must be met but do not significantly increase motivation. Whereas to optimally increase motivation, motivational factors are needed that are more than just meeting basic needs. Some other psychologists have even examined the occurrence of motivation in carrying out activities and determine factors that can increase motivation or decrease individual motivation.

Companies that have realized the importance of understanding employee motivation will always maintain factors that can improve employee performance. Motivation is said to be successful if within the employee concerned arises high morale to improve performance in a company.

Salam Indonesia travel is one of the travel agents engaged in the field of Hajj and Umrah. Travel was founded by $\mathrm{H}$. Edy $\mathrm{Fr}$, who has been established for almost 10 years. The concept of this travel is to make people able to perform Hajj or Umrah and, at the same time, make themselves prosperous. Based on the description above, then to answer these problems and sharpen the discussion, the author is interested in researching " The Application of Good Work Motivation to Increase Employee Productivity Salam Indonesia Travel."

\section{THEORY/CALCULATION Employee Performance}

(Turnbull et al., 2010) characterizes workers as "individuals who are paid to work for someone" (p.480). World Workers' union explains that workers are individuals who do work for public or private companies and receive compensation, commissions, tips, piece rates (wages in-kind). While performance is motivation and capacity. For total assignments and jobs, an individual must have a certain level of desire and level of capacity. Desires and individual abilities are not feasible in doing work without a clear understanding.

The level of individual performance is influenced by factors related to the work itself, which combine conflicting roles and work / not work (Jayaweera, 2015). A person's performance is a combination of mastery, business, and vacancies so that they can be judged by their work (Handayani, 2015). A person's performance is influenced by the mobilization of energy, capacity, and environmental conditions (Riyanto, Wijaya, \& Soerojo, 2016).

Another explanation about performance, according to (Riyanto et al., 2017), says that performance is the result accomplished by individuals through a measure determined for the work in question. According to Setyo et al., that performance is the result of the work of a worker or an activity carried out for a certain amount of time. In general, the overall performance of workers breaks even with the number (normal) of activities carried out by workers.
(Mangkunegara, 2011), said that the measurement of worker performance could be measured through five dimensions; in particular, there is the quality of work, the number of occupations, commitments, participation, and activities.

Research has suggested that current rewards result in fulfilling employee satisfaction, which specifically impacts employee performance. Gifts are management instruments that ideally affect an organization by impacting the behavior of the individual or bunch. All organizations utilize salary, progress, rewards, or other sorts of rewards to empower and energize high-level employee performance. Therefore, managers must consider a compensation structure that is significant and comprehensive

Leadership is doing things the right way, to do it only requires individuals to follow the leader, and they trust you. If both of these are to be achieved, they must be motivated (Baldoni, 2005). A theory concludes that a leader and his workers increase each other's quality and deep motivation (Rukmani, Ramesh, \& Jayakrishnan, 2010). Motivation is a simple behavior and authority. This goes from having to do what is good for individuals and organizations. Leadership and motivation have a dynamic nature (Baldoni, 2005).

Reinforce organizational benefits and make sense of possession and pride within the world of work. This builds on affiliations that are by and large useful between the organization and workers, which is considered as the perfect environment in several organizations and occupations. The workers involved focus their work and day-to-day work with extra centrality, and this leads to unfaltering progress in coordination and work methodologies. Workers perform their best interests and reflections with a feeling of having a place, enthusiasm, and charm, in a possible organization. Including they work with a sense of commitment and inclination towards the benefits of the organization for them (Yazdani, Yaghoubi, \& Giri, 2011).

Trust is characterized as a person's affirmation of others, the choice to act based on their discourse, behavior, and choices. when a company needs to develop and be effective, trust plays an imperative role so it must be continued to guarantee the company's presence and increment employee motivation (Annamalai, Abdullah, \& Alazidiyeen, 2010), This will make intrapersonal and interpersonal impacts on the inside and outside the company association.

Staff preparation is an important technique for spurring employees. One way supervisors can influence motivation is to provide data that is appropriate in the sentence of their activities to others. 


\section{Why Motivate Employees}

Improving the adequacy of the performance of each company and also its development based on its main resources, workers, and the ability of supervisors to form a motivating atmosphere for their workers. In addition, it might be a challenge for leaders to keep individuals and their workers motivated, and their needs met. In this way, why every manager must pay attention to almost all the requirements and needs of their workers and what they are searching for.

Motivated workers can influence company income and create the work environment that some workers want as a put to interact with one another, not just as a place to "receive a salary" (Nandanwar, Surnis, \& Nandanwar, 2010) In addition, wellmotivated organizations will undoubtedly have more workers being encouraged, and subsequently, they will be more profitable, and this will lead to reserve funds being taken.

A company whose workers have low motivation so that the organization is powerless in facing challenges inside and outside because workers do not try hard to maintain organizational stability. Unstable organizations end up performing poorly. Companies must encourage/motivate their individuals and keep them to improve efficiency and maintain their competitiveness. Some individuals who are committed will feel propelled and do their best and work hard right.

(Mansoor, 2008), states that motivation can create an environment where workers will be encouraged, and subsequently, workers can work with their best quality. And also the company must encourage each worker to increase their competitive focal point and accomplish the required objectives of the company (Philip, C.T., Yu-Fang, Y., LiangChih, H., 2007). An analysis says that satisfied and energized workers are essential for organizational viability (Yee, Yeung, \& Cheng, 2010).

Spurring individual motivation and their commitment is very important for work efficiency because they will emerge with full potential and with high quality and (Samuel \& Chipunza, 2009), state that having a motivated workforce will provide competitive advantages needed by the companies and superior implementation of workers in making improvements to the quality of the organization to achieve higher productivity.

\section{High Achievement Motivation Will Improve Employee Performance}

The need for high achievers is an impetus that arises in a person to achieve the targets set. According to McClelland, behavioral traits of individuals who have a high-achievement motivation like responsibility for solving problems; tend to set difficult targets and have the courage to take consequences; has clear goals and makes sense; have a good work arrangement; and happy with the task done and always want to complete it perfectly. Instead, the characteristics of individuals who have low achievement motivation are being apathetic and not confident; they do not have personal responsibility at work; they work without clear plans and goals; every action is not restrained and deviates from the goal.

Between achievement motivation and the level of performance, there is a significant relationship (Huwaidaul Azkiya, 2020) That is, individuals who have high achievement motivation will tend to have high levels of performance. Conversely, those with low achievement motivation are likely to get low performance.

\section{METODE}

The type of research that the author uses in this journal is a type of qualitative descriptive research that is the type of research by collecting data in the form of words, images, and not numbers that aim to present conclusions in the form of descriptions or sentences without using statistical calculations. Or it will only search and collect data to obtain an overview of The Importance of Work Motivation in Increasing the Productivity of Salam Indonesia Travel Employees. Information collection procedures utilized in this study are the strategy of perception, interviews, and documentation considers. Information examination procedures in this study include the steps of data reduction, data display, and drawing conclusions.

\section{RESULTS AND DISCUSSION Motivation and Work Productivity in Salam Indonesia Travel}

The significance of motivation and work productivity in Salam Indonesia Travel, namely to attain the objectives of the company, motivation has an important role because it is an effort of leaders to inspire, encourage, and create better morale for their employees. Likewise, important factors employee productivity in Salam Indonesia Travel is high employee performance arising from the motivation of leaders to employees to work optimally and correctly by their respective duties.

(Suaib, 2016) Work motivation can be a condition where workers need a full appreciation of their work, get something comfortable at work, security at work, good salary/wages, appealing work, and shrewd teach from every leader. One of the factors that affect work efficiency is the completion of work where one of them is the issue of work motivation that's not done by the leader. Work motivation is a condition in an organization that wants to increase profits that are greater than before; in this manner, work motivation plays a 
critical part in shaping the most extreme productivity.

The purpose of work motivation is to supply assurance to each worker so that workers can carry out their commitments effectively and productively. The effect happens in the event that there's no work motivation within the company, where workers will carry out their work in a standard way and need eagerness in carrying out their work.

Without the motivation from the leader of Salam Indonesia Travel, the work productivity of employees will decrease because the employees are not motivated to carry out their work so that the work done is not completed to the maximum, the result is the performance of employees of Salam Indonesia Travel will decline.

\section{The role of motivation in improving the performance of Salam Indonesia Travel employees}

The role of motivation is very important for Salam Indonesia Travel as an encouragement for an employee to continue to excel at work. Travel Salam Indonesia is motivating to improve the performance of its employees. (Putri, Nuringwahyu, \& Hardati, 2019) Tall accomplishments can lead to a representative working climate that will be great so that it can empower openness on the portion of both employees and leaders. Work peace will work well so that it can affect employee performance.

As it has been revealed that the role of motivation in improving the performance of Salam Indonesia Travel employees, there are 5 types as follows:

a) A clear job description can improve the performance of Salam Indonesia Travel employees.

Salam Indonesia Travel has a way for workers to be effective in their work by providing an appropriate schedule so that employees understand the schedules that have been determined. The leader of Salam Indonesia Travel also gives responsibility to its employees to be able to work in each section so as not to forget the tasks that have been given. The leader of Salam Indonesia Travel also has a way for employees to have the ability to be creative and initiative in their work, namely by briefing every day. The leader of Salam Indonesia Travel also provides an opportunity for employees to give and receive advice, with these suggestions will increase employee morale at work.

b) Effective communication of superiors with Salam Indonesia Travel employees.

Salam Indonesia Travel has provided information or briefing every day before work. Providing information or feedback is an important element for everyone in an organization. Providing feedback is usually done by managers or supervisors to tell employees where employees must carry out their respective duties in terms of realizing the goals of the organization. Employees who still make mistakes at work will be given a warning so they can correct the mistakes that have been made. The purpose of providing feedback is to provide guidance, provide good information to support effective employee behavior, guide an employee who has made a mistake or does not understand the tasks set in the organization so that it becomes a good and successful performance.

c) Giving recognition for the work performance of Salam Indonesia Travel employees that can improve employee performance.

Salam Indonesia Travel in seeing employee skills can be measured from the level of employees that are tailored to the job that is their job or the responsibility of employees in completing work. Good work skills and work results of employees will be given recognition from the leader of Salam Indonesia Travel to employees who really deserve recognition. Job performance is related to the achievement of results from work standards set by an organization. Good work result is if the employee is active in working and able to carry out the assigned tasks properly.

d) Salam Indonesia Travel provides opportunities for employees to participate in the decision process that can improve employee performance.

Salam Indonesia Travel has provided opportunities for employees to work freely. The purpose of these freedoms is that employees must continue to follow established company regulations. Freedoms that have been given Salam Indonesia Travel, for example, are allowed to work while taking lectures. The leader of Salam Indonesia Travel also has demands for their employees to increase their responsibilities to work well, especially to enter according to a predetermined schedule.

e) Transfer of position can improve the performance of employees in Salam Indonesia Travel.

Salam Indonesia Travel has provided opportunities for employees to develop at work. The leader of Salam Indonesia Travel also provides motivation for employees to work well, giving encouragement to employees so that employees can develop. The leader of Salam Indonesia Travel, also provides opportunities for employees to move to other positions. Switching positions provides a second chance to organize a better career or build a better relationship. Switching positions in one's career have a better impact as long as it has been through careful preparation, including 
measuring the ability of self and personal interests of an employee.

\section{Employee Productivity Salam Indonesia Travel}

Salam Indonesia Travel always wishes that its employees can increase high work productivity. Because employee productivity is the most important thing in achieving organizational goals with high work productivity of employees, it enables a higher level of success in achieving its goals.

(Nasution, 2014) Productivity is a view of life and a mental attitude that always strives to improve the quality of life so that the condition is getting better and better. Because productivity is the effectiveness and efficiency of employees work in carrying out their work. Whether or not the work achieved is highly dependent on the ability of leaders to empower human resources at work must be productive, but institutionally also needs to be considered so that the overall work productivity of the institution can increase.

Employee productivity is not only influenced by the amount of salary/wages received or the ability of companies/agencies to improve the standard of living of their employees. But employee work productivity is also influenced by many factors. Some of these factors are Interesting work, safety, and protection at work, a good work environment, Good wages, promotion, Feel involved in organizational activities, etc.

There are several activities and efforts undertaken by the leader of Salam Indonesia Travel in expanding the work efficiency of its workers, namely (1) providing the widest possible opportunity for each employee to participate in training that is appropriate to their field of work, (2) the distribution of job to each working staff with the skills of the employees themselves, (3) placing employees in the right job positions, (4) rewarding employees who are performing well and giving penalties to employees who are not performing well.

\section{Linkages of Work Motivation and Work Productivity of Salam Indonesia Travel employees}

From the results of research in Salam Indonesia Travel, it was found that the implementation of work motivation has a bearing in increasing employee work productivity. Because employee productivity is a capacity to carry out activities that create a thing according to the specified quality in a shorter time than a workforce. (Nasution, 2014) Each company will have a distinctive policy on its human resources to attain worker efficiency. In fulfilling employee work efficiency, numerous components influence employee work efficiency, including work motivation, work teach, work fulfillment, and expanded employee push. The fourth that influences the work productivity of a worker is expected to be able to supply a way for employees to attain way better work efficiency since the most reason of work motivation is to supply an enthusiastic work spirit to each worker so that workers can carry out their obligations suitably and viably.

Salam Indonesia Travel leadership motivation will be adjusted to the assessment criteria for success in carrying out its leadership functions because motivation and productivity are an interrelated part of one another. Increased work motivation will affect an increase in employee productivity.

However, what needs to be remembered by the leaders of Salam Indonesia Travel is that good productivity cannot be formed without being influenced by supporting factors, such as (1) Training, (2) Mental and physical abilities of employees, (3) creating relationships that are harmony between employees and leaders and fellow employees. Therefore, if employees are treated well by superiors or there is a good relationship between employees, then the employee will participate well in work so that it will influence the level of work efficiency.

\section{CONCLUSION}

Based on the data obtained and the results of the research conducted in the previous chapters, it can be concluded as takes after:

The significance of motivation and work productivity in Salam Indonesia Travel, namely to attain the objectives of the company, motivation has an important role because it is an effort of leaders to inspire, encourage, and create better morale for their employees. Likewise, important factors employee productivity in Salam Indonesia Travel is high employee performance arising from the motivation of leaders to employees to work optimally and correctly in accordance with their respective duties.

The role of motivation is very important for Salam Indonesia Travel as an encouragement for an employee to continue to excel at work. Travel Salam Indonesia is motivating to improve the performance of its employees. Tall accomplishments can lead to a representative working climate that will be great so that it can empower openness on the portion of both employees and leaders. 
Salam Indonesia Travel in expanding the work efficiency of its workers by (1) providing the widest possible opportunity for each employee to participate in training that is appropriate to their field of work, (2) the distribution of job to each working staff in accordance with the skills of the employees themselves, (3) placing employees in the right job positions, (4) rewarding employees who are performing well and giving penalties to employees who are not performing well.

The work motivation of Salam Indonesia Travel employees has a bearing on increasing work productivity. Salam Indonesia Travel leadership motivation will be adjusted to the assessment criteria for success in carrying out its leadership functions. Because motivation and productivity are an interrelated part of one another. Increased work motivation will affect an increase in employee productivity.

\section{REFERENCES}

Annamalai, T., Abdullah, A. G. K., \& Alazidiyeen, N. J. (2010). The mediating effects of perceived organizational support on the relationships between organizational justice, trust and performance appraisal in Malaysian secondary schools. European Journal of Social Sciences, 13(4), 623-632.

Baldoni, John. (2005). Motivation Secrets. Great Motivation Secrets of Great Leaders.

Handayani, R. D. (2015). The influence of work motivation and work environment to the performance of library staff of ten November institute of technology (ITS) Surabaya. Journal of Public Administration and Bureaucracy, 8(5), 35-42.

Huwaidaul Azkiya, Setyo Riyanto. (2020). The Importance of Work Motivation for Improving Employee Performance. Retrieved from https://www.academia.edu/42795529/The_Imp ortance_of_Work_Motivation_for_Improving_E mployee_Performance

Jayaweera, Thushel. (2015). Impact of work environmental factors on job performance, mediating role of work motivation: A study of hotel sector in England. International Journal of Business and Management, 10(3), 271.

Mangkunegara, A. (2011). Human Resource Management Company. Bandung: PT Youth Rosdakarya. Eur. J. Bus. Manag, 9(31), 101106.

Mansoor, H. (2008). Motivation: A Challenge for Oil and Gas Companies an Omani Case Study",
Oil and Gas Business. Journal of Controlled Release, 126(3), 187-204.

Nandanwar, M. V, Surnis, S. V, \& Nandanwar, L. M. (2010). Intervening factors affecting the relationship between incentives and employee motivation: a case study of pharmaceutical manufacturing organisation in Navi Mumbai. Journal of Business Excellence, 1(2), 6.

Nasution, Ernawaty. (2014). Analisis Pengaruh Motivasi kerja dan Kepemimpinan Terhadap Kinerja Karyawan. Jurnal Al Bayan, 20(29).

Philip, C.T., Yu-Fang, Y., Liang-Chih, H. (2007). A study on motivating employees' learning commitment in the post-downsizing era: Job satisfaction perspective. Academy of Management Journal, 42(2), 157-169.

Putri, Ekawati Ningtyas, Nuringwahyu, Sri, \& Hardati, Ratna Nikin. (2019). PERANAN MOTIVASI DALAM UPAYA MENINGKATKAN KINERJA KARYAWAN (STUDI PADA BANDUNG SUPER MODEL MALANG). JIAGABI, 8(1), 26-32.

Riyanto, Setyo, Sutrisno, Ady, \& Ali, Hapzi. (2017). The Impact of Working Motivation and Working Environment on Employees Performance in Indonesia Stock Exchange. International Review of Management and Marketing, 7(3), 342-348.

Riyanto, Setyo, Wijaya, H., \& Soerojo, D. (2016). Selling Yourself: Menang Bersaing di Era MEA. Jakarta: Kaifa, MarkPlus Inc.

Rukmani, K., Ramesh, M., \& Jayakrishnan, J. (2010). Effect of leadership styles on organizational effectiveness. European Journal of Social Sciences, 15(3), 365-369.

Samuel, Michael O., \& Chipunza, Crispen. (2009). Employee retention and turnover: Using motivational variables as a panacea. African Journal of Business Management, 3(9), 410415.

Suaib, Suhaemi. (2016). Pentingnya Motivasi Kerja dalam Meningkatkan Produktivitas Kerja Pegawai Kantor Urusan Agama di Kecamatan Bontomarannu. Skripsi, UIN Alauddin.

Turnbull, Joanna, Lea, D., Parkinson, D., Phillips, P., Francis, B., Webb, S., Bull, V., \& Ashby, M. (2010). Oxford advanced learner's dictionary. International Student's Edition.

Yazdani, B. O., Yaghoubi, N. M., \& Giri, E. Sami'pour. (2011). Factors affecting the Empowerment of Employees. European Journal of Social Sciences, 20(2), 267-274.

Yee, Rachel W. Y., Yeung, Andy C. L., \& Cheng, T. C. Edwin. (2010). An empirical study of employee loyalty, service quality and firm performance in the service industry. 


\section{Copyright holder:}

Huwaidaul Azkiya, Setyo Riyanto (2020)

First publication right :

Journal of Social Science

This article is licensed under:

(c) (i) (?) 